\title{
Inhibition of dipeptidyl peptidase-4: The mechanisms of action and clinical use of vildagliptin for the management of type 2 diabetes
}

This article was published in the following Dove Press journal:

Diabetes, Metabolic Syndrome and Obesity:Targets and Therapy

II June 2009

Number of times this article has been viewed

\author{
Galina Smushkin \\ Adrian Vella \\ Division of Endocrinology, Diabetes, \\ Metabolism, and Nutrition, Mayo \\ Clinic College of Medicine, Rochester, \\ MN, USA
}

\begin{abstract}
Postprandial hyperglycemia in type 2 diabetes is characterized by impaired insulin secretion and action, decreased glucose effectiveness and defective suppression of glucagon secretion. Newly available therapies for type 2 diabetes target the pathway of the incretin hormone glucagon-like peptide-1 (GLP-1). Oral inhibitors of dipeptidyl peptidase-4 (DPP-4) raise the level of endogenous GLP-1 by inhibiting its clearance thereby lowering fasting and postprandial glucose concentrations. Unlike compounds which act as agonists of the GLP-1 receptor, DPP-4 inhibitors are not associated with significant effects on gastrointestinal motility, which led to a controversy around the mechanisms responsible for their glucose-lowering effects. Here we review the evidence in regards to the mechanisms whereby DPP-4 inhibitors lower glucose concentrations. Their effects are most likely mediated by an increase in endogenous GLP-1, although additional mechanisms may be involved. The pharmacology, efficacy and safety of vildagliptin, a novel DPP-4 inhibitor, are also discussed.
\end{abstract}

Keywords: insulin secretion, insulin action, incretin, DPP-4 inhibitor, glucagon-like peptide 1

\section{Introduction}

Of the 20.8 million Americans with diabetes, 90\%-95\% have type 2 diabetes. This disorder is primarily characterized by defective insulin secretion and action. Other mechanisms that contribute to postprandial hyperglycemia in patients with type 2 diabetes are an impaired ability of glucose to stimulate its own uptake and suppress its own production (glucose effectiveness), defective suppression of glucagon secretion and possibly altered gastric motility.

Incretins are gut hormones that amplify insulin release in response to an oral glucose load. They include glucagon-like peptide (GLP-1) and glucose-dependent insulinotropic polypeptide (GIP). Altered meal-stimulated GLP-1 secretion has been reported in people with type 2 diabetes. There is significant heterogeneity in these reports, with some studies showing 15\%-20\% impairment in GLP-1 secretion in patients with type 2 diabetes $^{1-5}$ and others showing enhanced secretion ${ }^{6}$ or no difference in secretion. ${ }^{7}$ The role of GLP-1 in the pathogenesis of type 2 diabetes remains controversial. GLP-1 secretion was found to be reduced in subjects with impaired glucose tolerance as well as people with impaired fasting glucose, suggesting abnormalities of incretin secretion may be present early in pre-diabetes. ${ }^{8}$ The precise role that the alterations in GLP-1 secretion play in the pathogenesis of pre-diabetes and diabetes is at present uncertain.

Regardless of whether endogenous incretin secretion is altered, acute exogenous GLP-1 administration increases insulin secretion, ${ }^{9}$ inhibits glucagon release ${ }^{10}$ and delays
Correspondence: Galina Smushkin Division of Endocrinology, Diabetes, Metabolism, and Nutrition, Mayo Clinic College of Medicine, 200 First ST SW,

Rochester, MN55905, USA

$\mathrm{Tel}+\mathrm{I} 5072842784$

Fax + I 5072845745

Email smushkin.galina@mayo.edu 
gastric emptying, ${ }^{11}$ all of which result in a glucose-lowering effect. Interestingly, pharmacologic doses of exogenous GIP have not demonstrated the same insulinotropic potency and tend to result in negligible glucose-lowering in people with type 2 diabetes..$^{12}$

The short half-life of GLP-1, due to its rapid degradation by the ubiquitous dipeptidyl peptidase-4 (DPP-4) enzyme, would require the hormone to be infused continuously to achieve therapeutic effect. This limitation to the therapeutic use of GLP-1 has been circumvented by the development of GLP-1 receptor agonists, resistant to the action of DPP-4, and of compounds that inhibit DPP-4, thereby raising endogenous concentrations of active GLP-1 and GIP (and perhaps other substrates of DPP-4). The arrival of incretin-based pharmacotherapy has been heralded by exenatide (a GLP-1 receptor agonist) and sitagliptin (a DDP-4 inhibitor) both US Food and Drug Administration (FDA)-approved for the treatment of type 2 diabetes. Other compounds such as liraglutide, another GLP-1 receptor agonist and vildagliptin, a DPP-4 inhibitor, are expected to become available for clinical use in the near future.

\section{Mechanisms of action}

Endogenous GLP-1 and GIP are produced by L- and K-cells respectively, dispersed in intestinal mucosa. Both GLP-1 and GIP are physiological substrates for DPP-4, which exists both as a cell surface-enzyme present on numerous cell types including kidney, enterocytes, hepatocytes, and endothelial cells, and as a soluble form in the circulation. The importance of DPP-4 in incretin inactivation in vivo was established in animal studies where peptide infusions into DPP-4 deficient rats resulted in reduced cleavage of intact GLP-1 (7-36) amide and GIP (1-42) to metabolites GLP-1 (9-36) amide and GIP (3-42). ${ }^{13}$ Human studies confirmed that DPP-4 is a principal determinant of circulating half-life of GLP-1 and GIP in both normal and subjects with type 2 diabetes. ${ }^{14,15}$

Other peptides and chemokines may also be subject to cleavage by DPP-4 if they contain alanine or proline at the second N-terminal position. Potential substrates include substance $\mathrm{P}$, neuropeptide $\mathrm{Y}$, peptide $\mathrm{YY}$, and growth hormone-releasing hormone (GHRH). While these may be pharmacologic substrates, there is limited evidence that they are in fact physiologic substrates, where DPP-4 activity leads to biologically significant alterations in the endogenous levels of these substances (other than perhaps PYY). ${ }^{16}$

Its physiologic role in inactivating GLP-1 makes DPP-4 enzyme a therapeutic target. Animal data suggests significant metabolic benefits of DPP-4 inhibition. Mice lacking DPP-4 entirely were found to be resistant to high-fat diet- induced obesity and have lower insulin concentrations with a greater glucose-lowering efficacy. ${ }^{17}$ Diabetic rat models treated with a variety of DPP-4 inhibitors demonstrated improved glucose tolerance, insulin sensitivity and improved hyperinsulinemia in a series of studies. ${ }^{18-21}$ Islet histology in mice treated with DPP-4 inhibitors followed by streptozotocin revealed greater $\beta$-cell mass suggesting improved $\beta$-cell survival. ${ }^{22,23}$

Human studies show significantly lower fasting and post-prandial glucose values in people with type 2 diabetes treated with DPP-4 inhibitors compared to placebotreated subjects. ${ }^{24-26}$ DPP-4 inhibitors produce this effect by increasing insulin secretion and lowering glucagon concentrations. In studies where DDP-4 inhibitors were administered over the course of several days or weeks, glucose levels were lower but fasting insulin concentrations, insulin concentrations after meal ingestion and C-peptide concentrations were found to be unaltered. ${ }^{24-26}$ This implies that insulin secretion for a given glucose concentration is increased, indicating an improvement of $\beta$-cell function. Physiologic modeling of postprandial glucose, insulin and C-peptide revealed a 50\% increase in the insulin secretion response to ambient glucose after six weeks of treatment with vildagliptin. ${ }^{25}$ Similar results were obtained with modeling $\beta$-cell responsivity after a single dose of vildagliptin ${ }^{27}$ and 10 days of treatment with vildagliptin. ${ }^{28}$

The effect of DPP-4 inhibition on islet $\alpha$-cells may be just as important as the effect on $\beta$-cells in improving both fasting and postprandial glycemia. Most studies have shown a decrease in meal-stimulated glucagon concentrations in patients treated with DPP-4 inhibitors. ${ }^{24-29}$ The effect may persist well beyond the immediate post-prandial period, lasting as long as 12 hours. ${ }^{27}$ Subjects with a more marked reduction in the glucagon response to meal ingestion seemed to have the largest reduction in glucose. ${ }^{25,26}$

Lower glucagon concentrations result in a decreased rate of endogenous glucose production (EGP) after a meal. In a single-dose administration study of vildagliptin which used a double tracer method, EGP suppression was statistically greater within 60 minutes of meal ingestion in vildagliptin-treated subjects compared to a placebo. The difference became progressively larger with time: EGP was $25 \%$ lower within four hours and 59\% lower at 14 hours post-meal. ${ }^{27}$ The enhanced suppression of EGP was noted to correlate with the increment in insulin to glucagon ratio. Similar findings of a reduction in post-prandial endogenous glucose level were made in a study where participants were 
treated with vildagliptin for six weeks. ${ }^{26}$ In our own study of vildagliptin administration to people with type 2 diabetes for 10 days, we did not observe a statistically significant difference in either fasting or post-prandial EGP. ${ }^{24}$ However, since glucose itself stimulates its own uptake and decreases glucagon production, comparable rates of endogenous glucose production at a lower plasma glucose level in the vildagliptin group, suggests that there is a net suppressive effect of vildagliptin on EGP.

The mechanism by which DPP-4 inhibition results in a lower glucagon secretion has not been established. One possibility is a direct inhibitory effect of GLP- 1 on the $\alpha$-cells. However, a study where glucagon levels were measured during a hypoglycemic clamp showed a $38 \%$ increase in glucagon response to hypoglycemia in vildagliptintreated subjects compared to the placebo group. ${ }^{30}$ In this same group of subjects, a standard meal resulted in a $41 \%$ decrease in postprandial glucagon compared to placebo. This suggests that DPP-4 inhibition produces an increased responsiveness of $\alpha$-cells, rather than a unilateral inhibitory effect. An intriguing possibility is that the $\alpha$-cells are more responsive to insulin in the presence of DPP-4 inhibition. In subjects receiving vildagliptin, intravenous administration of insulin five hours post-meal ingestion resulted in a marked suppression of glucagon to a nadir, which was not seen in the presence of placebo. ${ }^{28}$

It has also been proposed that DPP-4 inhibition alters insulin action and glucose effectiveness. Some ${ }^{31,32}$ but not all studies ${ }^{33}$ have shown increased glucose effectiveness when GLP-1 is administered in pharmacologic doses. Therefore, it is not an unreasonable expectation that similar effects may be seen with DPP-4 inhibition which increases endogenous levels of GLP-1. However, we observed no change in glucose effectiveness and insulin action after 10 days of treatment with vildagliptin. ${ }^{28}$ In the same study, the glucose-lowering effects of exogenously-administered insulin (a model-independent measure of insulin action) was unchanged by vildagliptin. In contrast, a study where subjects were treated with vildagliptin for six weeks and a euglycemic hyperinsulinemic clamp was used to measure insulin-stimulated systemic glucose utilization, found the latter to be slightly but significantly higher with vildagliptin treatment. ${ }^{26}$ This however may be a reflection of decreased glucotoxicity and lipotoxicity associated with a longer duration of DPP-4 inhibitor therapy. In another short-term study, where a single dose of vildagliptin was administered, there was no improvement in glucose disposal, ${ }^{27}$ which is consistent with our findings.
Unlike GLP-1 and exenatide which delay gastric emptying when administered in pharmacologic doses, DPP-4 inhibition has little effect on gastrointestinal motility. Our study of people with type 2 diabetes treated with vildagliptin did not show a difference in gastric emptying, ${ }^{24}$ gastric volume or satiation. ${ }^{34}$ This is congruent with the observation that unlike the GLP-1 analogue exenatide, the DPP-4-inhibitors do not increase the frequency of gastrointestinal side-effects such as prandial fullness, nausea or vomiting.

The absence of effect of DPP-4 inhibition on gastric emptying raises the question whether all therapeutic actions of DPP-4 inhibitors are mediated by GLP-1. Indeed, there has been some controversy with regards to the mode of action of DPP-4 inhibitors. ${ }^{35,36}$ Although all studies of DPP-4 inhibition demonstrate an increase in the level of circulating GLP-1, the magnitude of this change is arguably small. ${ }^{35}$ The infusion of an equivalent amount of GLP-1 has little insulinotropic activity in healthy subjects and subjects with type 2 diabetes. ${ }^{37}$ However, GLP-1 concentration in the systemic circulation may be of a lesser physiologic relevance than the portal circulation concentrations and the local concentration in the lamina propria of gastrointestinal mucosa. Higher local and portal concentrations of GLP-1 may activate afferent sensory nerves of the gut leading to increased vagal stimulatory activity to the pancreas. ${ }^{36}$ The potential role of this neural pathway is suggested by the finding of GLP-1 receptor expression in the nodose ganglion cells, ${ }^{38}$ as well as by an increase in vagal trunk activity seen after intraportal administration of GLP- $1 .^{39}$

The same parasympathetic nervous activation mechanism may explain the absence of effects of DPP-4 inhibitors on gastrointestinal motility. In a study during which GLP-1 was infused intravenously in people with type 2 diabetes, glucose-lowering was observed with all doses, but gastric emptying was inhibited in a dose-dependent manner. ${ }^{40}$ This suggests that higher GLP-1 concentrations may be needed to produce effects on the afferent sensory neuron receptors of the gastrointestinal tract that result in slowing of intestinal motility.

Since DPP-4 inhibitors are weight-neutral and have no significant gastrointestinal effects it has been suggested that this may be explained by altered concentrations of peptides other than GLP-1, particularly NPY and PYY. NPY is an abundant neuropeptide in the central and peripheral nervous system, involved in the control of feeding and energy homeostasis. PYY is produced by endocrine cells of the small intestine and colon in response to a meal and has several inhibitory functions. Both are 
substrates of DPP-4 enzyme and their truncation by the enzyme reduces their activity on $\mathrm{Y} 1$ receptor located in the cerebral cortex while preserving agonist activity on Y2 and Y5 receptors. ${ }^{41}$

In contrast, studies in mice with combined genetic disruption of both GIP and GLP-1 receptors (double incretin receptor knockout) DIRKO mice provide evidence that GIP and GLP-1 are the principle peptides responsible for the glucose-lowering effects of DPP-4 inhibitors. When these mice were treated with vildagliptin for eight weeks, there was no improvement in insulin secretion and no lowering of blood glucose, whereas these effects were present in the wild-type control group. ${ }^{42}$ Other DPP-4 inhibitors were similarly ineffective in lowering blood glucose after an oral glucose challenge in DIRKO mice. ${ }^{43}$

In summary, it seems that DPP-4 inhibitors lower glucose concentrations through their effects on insulin and glucagon secretion. There is no consistent evidence that they improve insulin action or glucose effectiveness. Gastric emptying is not inhibited. These effects are most likely mediated by an increase in endogenous GLP-1, although additional mechanisms may be involved.

\section{Pharmacology}

The pharmacokinetics of vildagliptin have been studied in healthy subjects and people with type 2 diabetes. ${ }^{44,45}$ Oral doses of 25-100 mg administered once or twice daily were used. Vildagliptin is rapidly absorbed and is not subject to significant first-pass metabolism, resulting in $85 \%$ oral bioavailability. ${ }^{44}$ Administration of vildagliptin with food has no clinically relevant effect on bioavailability. ${ }^{46}$ Maximal concentration occurs one hour after administration regardless of the dose. Its elimination half-life in plasma is short (average $2.8 \mathrm{hrs}$ ), yet its effects on DPP-4 inhibition are longlasting with $86 \%$ and $95 \%$ 24-hour inhibitory effect at $25 \mathrm{mg}$ twice daily and $100 \mathrm{mg}$ twice daily doses, respectively. ${ }^{45}$ This is likely related to the extensive distribution of the drug into the tissue: the volume of distribution in the steady state is $71 \mathrm{~L}^{47}$

Vildagliptin undergoes hydrolysis in the liver, with a smaller (20\%) contribution from the DPP-4 enzyme itself. ${ }^{44}$ The principle hydrolysis reaction yields the major carboxylic metabolite which is inactive. This does not involve the p450 system, making the potential for drug-drug interactions low. When vildagliptin was studied specifically in combination with commonly used antihypertensive medications (amlodipine, valsartan, and ramipril) no significant interactions were found. ${ }^{48}$ Final elimination of vildaglipitin metabolites is via the kidney, where one third of the drug is excreted in an unchanged form. ${ }^{44}$

\section{Efficacy}

A number of studies investigated the efficacy of vildagliptin in the treatment of drug-naïve patients with type 2 diabetes. ${ }^{49-54}$ Mostly, these were six months in duration, with several studies spanning more than 12 months. ${ }^{49,50,52}$ Total doses of $50 \mathrm{mg}$ or $100 \mathrm{mg}$ daily were used, administered on a once or twice daily schedule. Hemoglobin $\mathrm{A}_{1 \mathrm{C}}\left(\mathrm{HbA}_{1 \mathrm{C}}\right)$ reduction from baseline ranged from 0.2 to $1.4 \%$. The reduction was greatest in patients with a higher baseline $\mathrm{HbA}_{1 \mathrm{C}}$. Thus, in a 52 -week trial of vildagliptin at a $50 \mathrm{mg}$ daily dose where patients had a baseline $\mathrm{HbA}_{1 \mathrm{C}}$ of 6.7 , there was only a $0.2 \%$ reduction in $\mathrm{HbA}_{1 \mathrm{C}}$ from baseline. ${ }^{49}$ However, in trials where baseline $\mathrm{HbA}_{1 \mathrm{C}}$ was higher, greater effect of vildagliptin on $\mathrm{HbA}_{1 \mathrm{C}}$ was observed. For example, in the trial comparing vildagliptin to metformin as initial monotherapy for type 2 diabetes, there was a $1.0 \%$ reduction from a baseline $\mathrm{HbA}_{1 \mathrm{C}}$ of $8.7 \%$ achieved on vildagliptin $100 \mathrm{mg}$ daily. ${ }^{52}$ Similarly, a trial comparing acarbose to vildagliptin $50 \mathrm{mg}$ twice daily as initial therapy in drug-naïve patients with a baseline $\mathrm{HbA}_{1 \mathrm{C}}$ of $8.6 \%$, a reduction of $1.4 \%$ was seen. ${ }^{55}$

In determining the potential therapeutic niche of vildagliptin, a number of questions arise. Will vildagliptin become a firstline agent in the treatment of type 2 diabetes? Metformin, the current first-line therapy, has a long, well-established track record of efficacy and safety. A 52-week trial comparing metformin (1000 mg twice daily) with vildagliptin (50 mg twice daily) in drug-naïve patients with type 2 diabetes, showed that the reduction in $\mathrm{HbA}_{1 \mathrm{C}}$ was significantly greater in the metformin group (1.4\% reduction) compared to vildagliptin (1.0\% reduction). ${ }^{52}$ Thus, noninferiority of vildagliptin to metformin was not established. The superiority of the metformin in reducing $\mathrm{HbA}_{1 \mathrm{C}}$ was primarily driven by the subgroup of patients with $\mathrm{HbA}_{1 \mathrm{C}}>8.0 \%$. In contrast, in patients with $\mathrm{HbA}_{1 \mathrm{C}}<8.0$, changes from baseline $\mathrm{HbA}_{1 \mathrm{C}}$ were similar in metformin and vildagliptin treatment groups. Metformin also led to an average weight loss of approximately $2 \mathrm{~kg}$, whereas vildagliptin was weight-neutral. Gastrointestinal side effects were twice as prevalent with metformin as with vildagliptin, leading to a higher discontinuation rate. Thus, for patients unable to tolerate metformin as first-line therapy due to gastrointestinal adverse effects, vildagliptin may provide a treatment alternative, and for patients with baseline $\mathrm{HbA}_{1 \mathrm{C}}<8.0 \%$ there may not be an efficacy trade-off in this substitution.

Does vildagliptin have disease-modifying properties to justify its use in preventing the progression of type 2 diabetes? 
A 56-week extension of a previously mentioned 52-week trial of vildaglipitin in drug-naïve subjects with type 2 diabetes ${ }^{49}$ proposed that vildagliptin attenuates the progressive deterioration in $\beta$-cell function. ${ }^{50}$ However, the results were modest at best. Although $\mathrm{HbA}_{1 \mathrm{C}}$ did not change significantly from baseline (6.6\% in the vildagliptin-treated subjects) over the two-year treatment period; this was primarily driven by the treatment effect in the first year. In the second year, $\mathrm{HbA}_{1 \mathrm{C}}$ increased significantly, albeit this increase was less than in the placebo group $(0.2 \%$ increase for vildagliptin and $0.5 \%$ for placebo). A four-week washout period at the end of the study suggested that the effects on $\beta$-cell function and $\mathrm{HbA}_{1 \mathrm{C}}$ may be maintained. However, the short duration of follow-up after the discontinuation of vildagliptin and lack of statistical robustness ( $p=0.058$ for between-group differences in the measure of $\beta$-cell function after washout) diminish the clinical significance of these findings.

Can vildagliptin be safely and effectively added as a second treatment agent and what advantages does it offer relative to other therapeutic options? A common scenario is failure to achieve target $\mathrm{HbA}_{1 \mathrm{C}}$ on metformin monotherapy. In these patients, a sulfonylurea or thiazolidinedione is commonly added to improve glycemic control. In a 52-week trial where patients inadequately controlled on a maximum dose of metformin were randomized to receive glimepiride (mean dose $4.5 \mathrm{mg}$ daily) or vildagliptin (50 mg twice daily), noninferiority of vildagliptin to glimepiride was demonstrated. ${ }^{56}$ Comparable $\mathrm{HbA}_{1 \mathrm{C}}$ reduction was seen in both groups $\left(-0.9 \%\right.$ in patients with baseline $\left.\mathrm{HbA}_{1 \mathrm{C}}>8 \%\right)$ and a similar proportion of patients $(54 \%-55 \%)$ in each group achieved $\mathrm{HbA}_{1 \mathrm{C}}<7 \%$. Notably, in the vildagliptin treatment group, a greater proportion of patients achieved target $\mathrm{HbA}_{1 \mathrm{C}}$ without hypoglycemia (50.9\% vs $44.3 \%$ in the glimepiride group). In marked contrast to glimepiride group, there were no severe hypoglycemic episodes among vildagliptin-treated patients and no discontinuation of therapy due to hypoglycemia. Another advantage of vildagliptin over glimepiride was that the former did not result in a weight gain, whereas glimepiride-treated subjects gained on average $1.5 \mathrm{~kg}$.

Other possible clinical scenarios include inadequate glycemic control on monotherapy with either a sulfonylurea or a thiazolidinedione. Studies suggest that the addition of vildagliptin to glimepiride or pioglitazone results in a significant proportion of patients achieving target $\mathrm{HbA}_{1 \mathrm{C}}<7 \%$. $^{57,58}$ When added to glimepiride $4 \mathrm{mg}$ daily, a $50 \mathrm{mg}$ dose of vildagliptin daily was similar to $100 \mathrm{mg}$ daily in efficacy of glycemic control, with $21 \%$ of patients attaining goal $\mathrm{HbA}_{1 \mathrm{C}}{ }^{57} 50 \mathrm{mg}$ dose was associated with no weight gain and less hypoglycemia than the $100 \mathrm{mg}$ dose. When added to pioglitazone $45 \mathrm{mg}$ daily, $100 \mathrm{mg}$ dose of vildagliptin confers an efficacy advantage with $36 \%$ of patients reaching $\mathrm{HbA}_{1 \mathrm{C}}$ goal compared to $29 \%$ of patients treated with the $50 \mathrm{mg}$ dose.$^{58}$ However, this is at the expense of an average $1.3 \mathrm{~kg}$ weight gain, which was not observed at the $50 \mathrm{mg}$ dose. Interestingly, peripheral edema occurred more frequently in patients receiving vildagliptin added to pioglitazone than those receiving placebo with pioglitazone, but the frequency was unrelated to vildagliptin dose.

Addition of vildagliptin to an insulin program was examined in a 24-week trial that enrolled patients with a mean $\mathrm{HbA}_{1 \mathrm{C}}$ of 8.4 , despite taking an average of 82 units of insulin daily. ${ }^{59}$ Vildagliptin $50 \mathrm{mg}$ twice daily added to the insulin program produced a reduction of mean $\mathrm{HbA}_{1 \mathrm{C}}$ by $0.3 \%$ relative to the placebo group. The overall effect was largely driven by patients older than 65 years who on average were taking less insulin (66 units daily). Insulin titration was permitted, leading to an increase in the insulin dose in both vildagliptin-treated and placebo-treated patients. Between the two groups, the difference in the insulin dose increase was not statistically significant. Nevertheless, vildagliptin-treated subjects experienced approximately $40 \%$ fewer hypoglycemic episodes and no severe hypoglycemia, leading the authors to speculate that DPP-4 inhibition may restore $\alpha$-cell pancreatic function thereby improving counter-regulatory glucagon secretion. One theoretically-appealing regimen is to add vildagliptin to a 24-hour insulin such as glargine. However, at present, clinical trials are needed to examine the efficacy of this particular combination regimen.

Patients who may benefit from DPP-4 inhibitors in general and vildagliptin in particular are the elderly. Diabetes management in this group is complicated by the frequent presence of renal impairment and other comorbidities. Efficacy and safety data pooled from five trials of vildagliptin that included subjects older than 65 years, suggests that vildagliptin is effective at lowering $\mathrm{HbA}_{1 \mathrm{C}}$ in this population and may in fact lead to a greater decrease in fasting plasma glucose and a small, but statistically significant weight loss. ${ }^{60}$ There was no increase in drug-related adverse effects among the elderly when compared to younger patients, even though two-thirds of the older patients had a mildly impaired renal function. Overall rates of hypoglycemia were low $(0.4 \%)$ and all the episodes were mild in severity. Thus, vildagliptin represents a promising option in the diabetes management of the older patients, but more dedicated long-term studies of this particular population are needed. 


\section{Safety and tolerability}

In the efficacy trials previously described, vildagliptin was generally well tolerated. Incidence of hypoglycemia was low and the hypoglycemic episodes that occurred were mild. Notably, when used in combination with insulin, vildagliptin resulted in a significant reduction in the frequency of hypoglycemic events compared to the combination of insulin and placebo. ${ }^{59}$ Effects on bodyweight were neutral and not statistically different from placebo. Gastrointestinal effects such as diarrhea, nausea, and abdominal pain were at least two-fold less frequent with vildagliptin than with metformin. ${ }^{52}$

A meta-analysis that combined available data for vildagliptin and sitagliptin found an increased risk of nasopharyngitis (risk ratio 1.0-1.4), urinary tract infection (risk ratio 1.0-2.2), and headache (risk ratio 1.1-1.7). ${ }^{61}$ An increased risk of headache was more evident with vildagliptin. Notably, gastrointestinal side effects were not increased relative to placebo.

The small increase in the risk of infection, although not statistically significant across all studies, may reflect the role of the DPP-4 enzyme in the regulation of immune function. Animal models suggest DPP-4 is important in the maintenance of the appropriate ratio of $\mathrm{CD}^{+} \mathrm{T}$ cells to natural killer cells in the spleen and in the circulation. ${ }^{62}$ Several chemokines that attract monocytes, lymphocytes, and natural killer cells are potential substrates for DPP-4. ${ }^{63}$ Cleavage by DPP- 4 could activate chemokines and alter immune signaling, and DPP-4 inhibition may theoretically impair chemotaxis and result in an increased susceptibility to infection.

\section{Conclusions}

DPP-4 inhibitors are members of a relatively new class of pharmacotherapy for type 2 diabetes. They improve glycemic control by enhancing $\beta$-cell responsiveness to ambient glucose and lowering post-prandial levels of glucagon. These effects are primarily mediated by decreased GLP-1 clearance resulting in higher concentrations of GLP-1, especially in the portal circulation. Other potential mechanisms of action are currently the subject of investigation. DPP-4 inhibitors effectively reduce $\mathrm{HbA}_{1 \mathrm{C}}$ with a low incidence of hypoglycemia. Other features include weight neutrality, infrequent gastrointestinal side effects and safety even when renal impairment is present. These attributes could make these agents particularly useful in the treatment of elderly patients. Long-term outcome studies with a focus on micro- and macrovascular complications are needed to further define the role of DPP-4 inhibitors in the treatment of type 2 diabetes.

\section{Disclosures}

Dr Vella has received grant support from Merck in the past year. The studies examining the mechanism of action of vildagliptin and commented on in this paper were investigator-initiated studies funded by Novartis. He has consulted for Sanofi-Aventis and CPEX Pharmaceuticals. Dr Smushkin reports no conflicts of interest in this work.

\section{References}

1. Nauck MA, Heimesaat MM, Orskov C, Holst JJ, Ebert R, Creutzfeldt W. Preserved incretin activity of glucagon-like peptide 1 [7-36 amide] but not of synthetic human gastric inhibitory polypeptide in patients with type 2 diabetes mellitus. J Clin Invest. 1993;91:301-307.

2. Visboll T, Krarup T, Deacon CF, Madsbad S, Holst JJ. Reduced postprandial concentrations of intact biologically active glucagon-like peptide in patients with type 2 diabetic patients. Diabetes. 2001;50: 609-613.

3. Toft-Nielsen MB, Madsbad S, Holst JJ. Determinants of the impaired secretion of glucagon-like peptide-1 in type 2 diabetic patients. J Clin Endocrinol Metab. 2001;86:3717-3723.

4. Muscelli E, Mari A, Casolaro A, et al. Separate impact of obesity and glucose tolerance on the incretin effect in normal subjects and type 2 diabetic subjects. Diabetes. 2008;57:1340-1348.

5. Meier JJ, Gallwitz B, Askenas M, et al. Secretion of incretin hormones and the insulinotropic effect of gastric inhibitory polypeptide in women with a history of gestational diabetes. Diabetologia. 2005;48: 1872-1881.

6. Vilsbøll T, Krarup T, Sonne J, et al. Incretin secretion in relation to meal size and body weight in healthy subjects and people with type 1 and type 2 diabetes mellitus. J Clin Endocrinol Metab. 2003;88: 2706-2713.

7. Vollmer K, Holst JJ, Baller B, et al. Predictors of incretin concentrations in subjects with normal, impaired, and diabetic glucose tolerance. Diabetes. 2008;57:678-687.

8. Laakso M, Zilinskaite J, Hansen T. Insulin sensitivity, insulin release and glucagon-like peptide-1 levels in persons with impaired fasting glucose and/or impaired glucose tolerance in the EUGENE2 study. Diabetologia. 2008;51:502-511.

9. Kjems LL, Holst JJ, Volund A, Madsbad S. The influence of GLP-1 on glucose-stimulated insulin secretion: effects on $\beta$-cell sensitivity in type 2 and nondiabetic subjects. Diabetes. 2003;52:380-386.

10. Holst JJ, Toft-Nielsen MB, Orskov C, Nauck M, Willms B. On the effects of glucagon-like peptide-1 on blood glucose regulation in normal and diabetic subjects. Ann N Y Acd Sci. 1996;805:729-736.

11. Schirra J, Wank U, Arnold R, Goke B, Katschinski M. Effects of glucagon-like peptide-1 (7-36) amide on motility and sensation of the proximal stomach in humans. Gut. 2002;50:341-348.

12. Elahi D, McAloon-Dyke M, Fukagawa NK, et al. The insulinotropic actions of glucose-dependent insulinotropic polypeptide (GIP) and glucagon-like peptide-1 (7-37) in normal and diabetic subjects. Regul Pept. 1994;51:63-74.

13. Kieffer TJ, McIntosh CH, Pederson RA. Degradation of glucosedependent insulinotropic polypeptide and truncated glucagon-like peptide 1 in vitro and in vivo by dipeptidyl peptidase IV. Endocrinology. 1995; 136:3585-3596.

14. Deacon CF, Nauck MA, Meier J, Hucking K, Holst JJ. Degradation of endogenous and exogenous gastric inhibitory polypeptide in healthy and in type 2 diabetic subjects as revealed using a new assay for the intact peptide. J Clin Endocrinol Metab. 2000;85:3575-3581. 
15. Deacon CF, Nauck MA, Toft-Nielsen MB, Pridal L, Willms B, Holst JJ Both subcutaneously and intravenously administered glucagon-like peptide I are rapidly degraded from the NH2-terminus in type II diabetic patients and in healthy subjects. Diabetes. 1995;44:1126-1131.

16. Vella A, Bock G, Giesler PD, et al. The effect of dipeptidyl peptidase 4 inhibition on gastric volume, satiation and enteroendocrine secretion in type 2 diabetes: a double blind, placebo-controlled crossover study. Clin Endocrinol (Oxf). 2008;69(5):737-744.

17. Conarello SL, Li Z, Ronan J, Roy RS, et al. Mice lacking dipeptidyl peptidase IV are protected against obesity and insulin resistance. PNAS 2003;100:6825-6830.

18. Pedersn RA, White HA, Schlenzig D, Pauly RP, McIntosh CH, Demuth HU. Improved glucose tolerance in Zucker fatty rats by oral administration of the dipeptidyl peptidase IV inhibitor Ile-thiazolidede. Metabolism. 1998;48:385-389.

19. Pospisilik JA, Stafford SG, Demuth HU, et al. Long-term treatment with the dipeptidyl peptidase IV inhibitor P32/98 causes sustained improvements in glucose tolerance, insulin sensitivity, hyperinsulinemia and beta-cell glucose responsiveness in VDF (fa/fa) Zucker rats. Diabetes. 2002;51:943-950.

20. Pospisilik JA, Stafford SG, Demuth HU, McIntosh CH, Pederson RA. Long-term treatment with the dipeptidyl peptidase IV inhibitor improves hepatic and peripheral insulin sensitivity in the VDF Zuker rat: a euglycemic-hyperinsulinemic clamp study. Diabetes. 2002;51:2677-2683.

21. Sudre B, Broqua P, White RB, et al. Chronic inhibition of circulating dipeptidyl peptidase IV by FE 999011 delays the occurrence of diabetes in male Zucker diabetic fatty rats. Diabetes. 2002;51:1461-1469.

22. Pospisilik JA, Martin J, Doty T, et al. Dipeptidyl peptidase IV inhibitor treatment stimulates beta-cell survival and islet neogenesis in streptozotocin-induced diabetic rats. Diabetes. 2003;52:741-750.

23. Mu J, Woods J, Zhou YP, et al. Chronic inhibition of dipeptidyl peptidase-4 with a sitagliptin analog preserves pancreatic beta-cell mass and function in a rodent model of Type 2 diabetes. Diabetes. 2006;55:1695-1704.

24. Vella A, Bock G, Giesler PD, et al. Effects of dipeptidyl peptidase-4 inhibition on gastrointestinal function, meal appearance, and glucose metabolism in type 2 diabetes. Diabetes. 2007;56:1475-1480.

25. Ahren B, Landin-Olsson M, Jansson PA, Svensson M, Holmes D, Schweizer A. Inhibition of dipeptidyl peptidase-4 reduces glycemia, sustains insulin levels, and reduces glucagon levels in type 2 diabetes. J Clin Endocrinol Metab. 2004;89:2078-2084.

26. Azuma K, Radikova Z, Mancino J, et al. Measurement of islet function and glucose metabolism with the dipeptidyl peptidase 4 inhibitor vildagliptin in patients with type 2 diabetes. J Clin Endocrinol Metab. 2008;93:459-464.

27. Balas B, Baig MR, Watson C, et al. The dipeptidyl peptidase IV inhibitor vildagliptin suppresses endogenous glucose production and enhances islet function after single-dose administration in type 2 diabetic patients. J Clin Endocrinol Metab. 2007;92:1249-1255.

28. Dalla Man C, Bock, Giesler PD, et al. Dipeptidyl peptidase-4 inhibition by vildagliptin and the effect on insulin secretion and action in response to meal ingestion in type 2 diabetes. Diabetes Care. 2009;32(1):14-18.

29. Rosenstock J, Foley J, Rendell M, et al. Effects of the dipeptidyl peptidase IV inhibitor vildagliptin on incretin hormones, islet function, and postprandial glycemia in subjects with impaired glucose tolerance. Diabetes Care. 2008;31:30-35.

30. Ahren B, Schweizer A, Dejaher S, et al. Vildagliptin enhances islet responsiveness to both hyper- and hypoglycemia in patients with type 2 diabetes. J Clin Endocrin Metab. 2009;94(4):1236-1243.

31. Prigeon RL, Quddusi S, Paty B, D'Alessio DA. Suppression of glucose production by GLP-1 independent of islet hormones: a novel extrapancreatic effect. Am J Physiol Endocrinol Metab. 2003;285(4):E701-707.

32. D'Alessio DA, Prigeon RL, Ensinck JW. Enteral enhancement of glucose disposition by both insulin-dependent and insulin-independent processes. A physiological role of glucagon-like peptide I. Diabetes. 1995;44(12):1433-1437.
33. Vella A, Shah P, Basu R, Basu A, Holst JJ, Rizza RA. Effect of glucagon-like peptide 1(7-36) amide on glucose effectiveness and insulin action in people with type 2 diabetes. Diabetes. 2000;49(4):611-617.

34. Vella A, Bock G, Giesler P, et al. The effect of dipeptidyl peptidase-4 inhibition on gastric volume, satiation and enteroendocrine secretion in type 2 diabetes: a double-blind, placebo-controlled crossover study. Clin Endocrinol. 2008;69:737-744.

35. Nauck MA, El-Ouaghlidi A. The therapeutic actions of DPP-IV inhibition are not mediated by glucagon-like peptide 1 . Diabetologia. 2006;48:608-611.

36. Holst JJ, Deacon CF. Glucagon-like peptide-1 mediates the therapeutic actions of DPP-IV inhibitors. Diabetologia. 2005;48:612-615.

37. Nauck MA, Heimesaat MM, Orskov C, Holst JJ, Ebert R, Creutzfeldt W. Preserved incretin activity of glucagon-like peptide 1 [7-36 amide] but not of synthetic human gastric inhibitory polypeptide in patients with type-2 diabetes mellitus. J Clin Invest. 1993;91:301-307.

38. Nakagawa A, Satake H, Nakabayashi H. Receptor gene expression of glucagon-like peptide-1, but not glucose dependent insulinotropic polypeptide, in rat nodose ganglion cells. Auton Neurosci. 2004;110:36-43.

39. Nishizawa M, Nakabyashi H, Uchida K, Nakagawa A, Niijima A. The hepatic vagal nerve is receptive to incretin hormone glucagon-like peptide-1, but not to glucose dependent peptide-1, but not to glucosedependent insulinotropic polypeptide, in the portal vein. J Auton Nerv Syst. 1996;61:149-154.

40. Meier JJ, Gallwitz B, Salmen S, et al. Normalization of glucose concentrations and deceleration of gastric emptying after solid meals during intravenous glucagon-like peptide 1 in patients with type 2 diabetes. J Clin Endocrinol Metab. 2003;88:2719-2725.

41. Mentlein R Dipeptidyl-peptidase IV (CD26) - role in the inactivation of regulatory peptides. Regul Pept. 1999;85:9-24.

42. Flock G, Zhnag GL, Duttaroy A, Drucker DJ. The classic incretin receptors for GLP-1 and GIP are essential for the sustained glucoregulatory actions of vildagliptin in mice. Diabetologia. 2006; 49:107.

43. Hansotia T, Baggio LL, Delmeire D, et al. Double incretin receptor knockout (DIRKO) mice reveal an essential role for the enteroinsular axis in transducing the glucoregulatory actions of DPP-IV inhibitors. Diabetes. 2004;53:1326-1335.

44. He H, Tran P, Smith $\mathrm{H}$ et al. Absorption, metabolism, and excretion of $\left[{ }^{14} \mathrm{C}\right]$ vildagliptin, a novel dipeptidyl peptidase 4 inhibitor, in humans. Drug Metab Dispos. 2009;37(3):536-544.

45. He YL, Serra D, Wang Y, et al. Pharmacokinetics and pharmacodynamics of vildagliptin in patients with type 2 diabetes mellitus. Clin Pharmakinet. 2007;46(7):577-588.

46. Sunkara G, Sabo R, Wang Y, et al. Dose proportionality and the effect of food on vildagliptin, a novel dipeptidyl peptidase IV inhibitor, in healthy volunteers. J Clin Pharmacol. 2007;47:1152-1158.

47. He YL, Sabo R, Balex S, et al. Absolute bioavailability of vildagliptin in healthy subjects. Clin Pharmacol Ther. 2006;79:P38.

48. He YL, Ligueros-Saylan M, Sunkara G, et al. Vildagliptin, a novel dipeptidyl peptidase IV inhibitor, has no pharmacokinetic interactions with the antihypertensive agents amlodipine, valsartan, and ramipril in healthy subjects. J Clin Pharmacol. 2008;48:85-95.

49. Scherbaum WA, Schweizer A, Mari A, et al. Efficacy and tolerability of vildagliptin in drug-naïve patients with type 2 diabetes and mild hyperglycæmia. Diabetes Obes Metab. 2008;10:675-682.

50. Scherbaum WA, Schweizer A, Mari A, et al. Evidence that vildagliptin attenuates deterioration of glycæmic control during 2-year treatment of patients with type 2 diabetes and mild hyperglycæmia. Diabetes Obes Metab. 2008;10:1114-1124.

51. Dejager S, Razac S, Foley JE, Schweizer A. Vildagliptin in drug-naïve patients with type 2 diabetes: a 24-week, double-blind, randomized, placebo-controlled, multiple dose study. Horm Metab Res. 2007;39:218-223.

52. Schweizer A, Couturier J, Foley JE, Dejager S. Comparison between vildagliptin and metformin to sustain reductions in $\mathrm{HbA}_{1 \mathrm{C}}$ over 1 year in drugnaïve patients with type 2 diabetes. Diabet Med. 2007;24:955-961. 
53. Rosenstock J, Baron MA, Dejager S, Mills D, Schweizer A. Comparison of vildagliptin and rosiglitazone monotherapy in patients with type 2 diabetes: a 24-week, double-blind, randomized trial. Diabetes Care. 2007;30:217-223.

54. Rosenstock J, Baron MA, Camisasca RP, Cressier F, Couturier A, Dejager S. Efficacy and tolerability of initial combination therapy with vildagliptin and pioglitazone compared with component monotherapy in patients with type 2 diabetes. Diabetes Obes Metab. 2007;30: 175-185.

55. Pan C, Yang W, Baron JP, et al. Comparison of vildagliptin and acarbose monotherapy in patients with type 2 diabetes: a 24 -week, double-blind, randomized trial. Diabet Med. 2008;25:435-441.

56. Ferrannini E, Fonseca V, Zinman B, et al. Fifty-two-week efficacy and safety of vildagliptin vs glimepiride in patients with type 2 diabetes mellitus inadequately controlled on metformin monotherapy. Diabetes Obes Metab. 2009;11:157-166.

57. Garber AJ, Foley JE, Banerji MA, et al. Effects of vildagliptin on glucose control in patients with type 2 diabetes inadequately controlled with a sulphonylurea. Diabetes Obes Metab. 2008;10:1047-1056.
58. Garber AJ, Schweizer A, Baron MA, Rochotte MA, Dejager S. Vildagliptin in combination with pioglitazone improves glycæmic control in patients with type 2 diabetes failing thiazolidinedione monotherapy: a randomized, placebo-controlled study. Diabetes Obes Metab. 2007;9:166-174.

59. Fonseca V, Schweizer A, Albrecht D, Baron MA, Chang I, Dejager S. Addition of vildagliptin to insulin improves glycæmic control in type 2 diabetes. Diabetologia. 2007;50:1148-1153.

60. Pratley RE, Rosenstock J, Pi-Sunyer FX, et al. Management of type 2 diabetes in treatment-naïve elderly patients. Diabetes Care. 2007;39:3017-3022.

61. Amori RE, Lau J, Pittas AG. Efficacy and safety of incretin therapy in type 2 diabetes. JAMA. 2007;298(2)194-206.

62. Yan S, Marguet D, Dobers J, Reutter W, Fan H. Deficiency of CD26 results in a change of cytokine and immunoglobulin secretion after stimulation by pokeweed mitogen. Eur J Immunol. 2003;33:1519-1527.

63. Vanhoof G, Goossens F, De Meester I, Hendricks D, Scharpe S. Proline motifs in peptides and their biological processing. FASEB J. 1995;9:736-744.

\section{Publish your work in this journal}

Diabetes, Metabolic Syndrome and Obesity: Targets and Therapy is an international, peer-reviewed open-access journal committed to the rapid publication of the latest laboratory and clinical findings in the fields of diabetes, metabolic syndrome and obesity research. Original research, review, case reports, hypothesis formation, expert opinion and commentaries are all considered for publication. The manuscript management system is completely online and includes a very quick and fair peer-review system, which is all easy to use. Visit http://www.dovepress.com/testimonials.php to read real quotes from published authors. 